\title{
GLOBAL COMMUNICATION ENVIRONMENT FOR B2B MARKETS
}

\author{
Aleš $\operatorname{Hes}^{1, *}$ \\ ${ }^{1}$ University of Finance and Administration in Prague, Estonska 500, CZ 101 00, Prague 10, Czech \\ Republic
}

\begin{abstract}
Currently, there is an unprecedented development of modern communication technologies in B2B markets. In the context of Industry 4.0, globalization influences are increasingly reflected in the new information technologies that are becoming the domain of communication in B2B markets. The manufacturing environment is shaped by the ability to work with Big Data Analysis, use computer simulation tools and augmented reality and today's phenomenon is evolving in the processing and business environment - linking the Internet of Things, Services and People to Potential production environment. An important role in this global interconnection of both manufacturing and processing - business environments is played by the communication conditions determined by sufficient capacity computing power. One of the real preconditions for B2B markets is to make full use of the cloud-based platform based on the establishment of dedicated data centres with the possibility of using high level of Service Level Agreement for B2B business partners. The paper deals with the evaluation and analysis of the possibilities of digitalization development in the company space, to examine the new global communication environment by using cloud computing and its impact on the quality of information service for customers. The influence of intercultural communication on the behaviour of business partners is examined.
\end{abstract}

\section{Introduction}

At present B2B markets are witnessing an uncommon expansion of modern communication technologies. In the context of Industry 4.0, globalization influences are reflected more and more in new information technologies, which are becoming a communications domain on B2B markets [1]. The manufacturing environment is formed by an ability to work with large volumes of data (Big Data Analysis), to use computer simulation and expanded reality tools (Augmented Reality) and in the processing and sales environment, the phenomenon of the day is reflected - the integration of the internet of things, services, and people depending on the potential of the manufacturing environment. Communications conditions determined sufficiently by capacity computational power play an important role in this global integration, both of the manufacturing environment and the processing/sales

\footnotetext{
*Corresponding author: ales.hes@mail.vsfs.cz
} 
environment [2]. One of the real prerequisites for B2B markets is to fully adopt cloud solutions platforms based on managing specialized data centres with the option to use high guarantees provided by contractual provisions (Service Level Agreement) for those business partners on the B2B market. To satisfy customer demand in the field of information technology in the B2B market, it is necessary to differentiate between a solution and a product, which is not always seen as one by the customer or business partner. To establish a decision as to whether a product or solution needs to be chosen, a number of questions must be posed to which the relevant decision leads. E.g.: what are the key requirements and needs of the business partner/customer, what products are necessary to solve the problem, and what is the possible ways they can be combination thereof; is it possible to satisfy the customer need using a product or a combination of products? To resolve the questions above, it is necessary to decide correctly whether the sales representative shall carry out the delivery in the form of a product, a product that can be modified by the customer, or an individual solution. In connection with the implementation of Industry 4.0, the B2B market is coming to be dominated by the phenomenon of integration of things, services, and people in the context of automation of process management and intelligent technology [3]. Typical features of Industry 4.0 include immediate accessibility of a product or service in the form of an online pathway [4]. This requires the full automation of inventory, full-fledged connection to online sales (ecommerce) in the form of digital payment options, various debit cards, or payment systems such as PayPal. A prerequisite of these digital systems for the customer is the automation of notifications to the customer and communication via web pages (microsites) with the option to set up self-service [5]. In principle, this is a customer configuration which allows adaptation of the customer product to the needs and preferences of the customer using a range of predefined variables. Everything is always considered with a proper form of communications between business partners.

\subsection{Resolving an offer in the Industry 4.0 environment}

According to Pricril the individual offering is considered in combination with products and services to represent somewhat of a "tailor made customer solution" [6]. This represents a significant level of customer modification of the product according to the customer's individual requirements. This product is custom developed and can be considered a unique original which will not appear anywhere else. Trueman defines a "solution" as the application of a product for resolving a specific customer requirement in a particular market industry such as banking, government, or the processing industry. The solution is based on a standard product, where its standard functions and the characteristics used in a specific extent. Or it could contain one or more modifications, custom client modifications, or it can contain integration with other customer solutions. The creation of prices is always individual for each case with individual documentation [7]. For example, Amazon as a provider of web services [8] offers (communicates) outside standard product offering and solutions offering. This is based on archival of data, backup and restoration of data, business applications, or database migration. From the perspective of business creation of "solutions" for customers, this represents a capability for reflection of customer needs and wishes using technical and technological skills. The basis is updating leadership and regular training of sales personnel and customers. In terms of management, this represents an alignment of the ideologies and strategies of the company with the decisions of company management. All of this using modern and effective communication tools. What is key for the B2B market are the aspects of Industry 4.0, which act in an integrated manner. 


\section{Methods}

The main methods used in the elaboration of this topic were structured analysis and forensic description of facts, synthesis methods, logical and deduction procedures in order to identify and formulate the impacts of global communication on the formation of B2B market relationships through cloud storage, affecting business behavior of Czech companies. The theme is organized according to the logic of facts and the deduction of results from the analysis of scientific texts into a unique meaning unit, which identifies the basic potential of cloud storage for the competitiveness of Czech companies in global markets.

\section{Results and Discussion}

According to Industry 4.0, companies act as "smart factories" that use cybernetic/physical systems for monitoring and controlling physical processes. The gradual implementation of the Industry 4.0 concept will take place using the methods of machine learning, autoconfiguration and auto-diagnostics, and total integration of machines and parts. Machines and products will be placed using computer chips that will enable their control and operation [9].

The main contours of Industry 4.0 have been formulated for the enterprise sphere as follows:

- Interoperability - mutual integration and cooperation of individual components of cybernetic/physical systems

- Virtualization - creation of a copy of the "Smart Factory" using data obtained from individual sensors and the option to simulate and analyse situations using cloud services almost in real time.

- Modularity - individual systems will be solved in the form of a modular system that enables adaptation and adjustment of operation of smart factories according to current needs [10].

Dachs et al. explore the relationship between support of manufacturing activities and technologies for digital production as part of Industry 4.0. They claim that it supports back shoring, because it provides higher productivity and flexibility [11]. Zhang et al. on the other hand present an architecture of the use of ubiquitous robotic systems based in the cloud for intelligent production of an adapted product. They present the framework for designing a ubiquitous robotic system based in the cloud (URS) which is composed of the functions, structures and behaviour of the URS. Afterward they provide a process for the development of such URS and maintain that the implementation of a ubiquitous robotic system based on the cloud for intelligent production and assembly of an adapted product shows that the proposed approach can achieve the goal of intelligent production of an adapted product through the development of ubiquitous robotic systems based in the cloud [12]. Kerin and Pham identify trends and gaps associated with the organizational matters in a company from the perspective of value creation with a refurbished product [13]. Findings suggest there is a need to explore the connection of cyber-physical systems to the IoT to support smart remanufacturing, whilst aligning with evolving information and communication infrastructures and circular economy business models. Liu et al. present failure modes and effects analysis (FMEA) as a useful technique for managing quality that is used in various industrial sectors for increasing the reliability and security of systems, products, processes, and services [14]. And yet traditional FMEA was criticized for numerous internal defects when evaluating failure modes and identifying risk factors and the order of failure modes that weaken its accuracy and effectiveness during application. Liu et al propose a new methodology for FMEA integrating the theory of the cloud model with expanded analysis using grey relational analysis (GRA) to resolve the disadvantages 
of the classic approach to the number of priority of a risk. The feasibility and practicality of the proposed FMEA are clarified on the basis of an empirical example from the paper industry. The results indicate that the new model for risk assessment is capable of producing more reliable results of assessment of risks caused by failure for risk reduction measures. One of the largest advantages of data storage in a cloud environment is the option for dynamic management of the required capacity and parameters of the environment $[15,16]$. In the cloud environment it is possible to increase the required space according to need. This activity would over time lead to limiting dedicated disk capacity of devices where data is stored in the event customer data is stored in a local repository (onpremise) [17]. For the cloud environment, very high guarantees of the service provided are typical [18]. The guarantees are provided, for example, for availability of a virtual server or repository, for a specific level of customer support, or for the minimization of risks of loss of customer data [19]. The most important standards include ISO 2700 certification for methods of managing security when handling information. Another important certification is PCI DSS, which defines conditions for operation, transmission, storage, and security of data for operations with payment cards [20]. One of the key parameters for providing cloud services is access to the internal and other networks. For cloud services, a stable, sufficiently fast, and secure connection is required. For access to customer systems and their integration with the end user or end point, most often certain types of private networks of the VPN (Virtual Private Network) type are used, which guarantee a high level of security. The types of VPN networks most commonly used are Site-to-Site and Client-toSite connections. Private networks of the Site-to-Site type are used for connecting the customer location with a different location. This can consist of a different branch office or location of the provider of cloud services. The client type of VPN remote access are the most commonly used for access by individual end users. These client VPNs allow for secure access even outside the internal network of the customer and therefore represent a high degree of mobility for their use and for cloud services as well. Using client networks it is possible to automatically back up and synchronize the content of end stations with secure content in s cloud environment [21].

We can include the following among the primary advantages of cloud services:

1. Operation of IT systems on modern and new HW without the need for capital investment - the data centre undergoes regular HW infrastructure replacement that corresponds to existing IT trends.

2. The option of a scaled solution thanks to almost unlimited IT performance without the need for maintenance, replacement, and repair.

3. Professional backups - customer data is backed up using the data centre backup system, which represents the most modern, high performance, easily usable solution for backup and accessibility.

4. Rapid restoration of data - customer data can be stored on multiple physical repositories and its restoration can be automated.

5. Professional online support - part of the solution consists of Service Desk services, which include:

- Continuous proactive IT monitoring of the operated solution (monitoring of system resources).

- $24 \times 7 \times 365$ Help Desk for reporting and resolving requests and service incidents in the case of cloud services.

- Logging of all service incidents and requests.

- Experienced and regularly trained servicing team for administration of the operated solution (L1, L2, and L3 support). 
- Availability - Service team is available continuously on location at the data centre - as a result, the customer does not have to deal with the availability of local IT.

6. Increased accessibility of IT systems - part of the solution includes guaranteed availability of the infrastructure operated at a level of up to $99.99 \%$ (Datacentre Level Tier 3).

7. Transparent costs for operation. Payment for service is addressed in the form of smaller fees (simplified cash flow - issues of OPEX vs. CAPEX).

8. Flexibility in increasing performance of services without need to invest in additional $\mathrm{HW}$.

9. The option for individual growth according to the Pay as You Go policy.

10. Transfer of responsibility for operation of technologies to the provider of the solution.

In terms of financing, the method of financing is the key difference between methods of data storage of on premise data. The on premise variant is at the base level financed in the form of CAPEX, i.e. in the form of one-off HW and SW purchases for the ownership of the customer. In the case of cloud repositories, it is always a question of specific form of services and method of financing in the form of OPEX, i.e. in the form of regular payments realized as a rule on a monthly basis [22]. Cloud repositories actually represent a great potential for a higher level of communication on the B2B market [23]. In the Czech Republic, they are used primarily as paid computing by large companies. According to the ČSÚ, the services that were being used in 2017 in the form of paid cloud computing include above all e-mail (17\%), storage of data and files (13\%), office software (11\%), database applications (9\%), accounting applications (8\%), CRM applications (5\%), and computing power. A pilot survey carried out by the independent telemarketing company ATODA Telemarketing s.r.o. in the form of an online questionnaire and using the telephone questionnaires of call centre operators, which was focused on small and medium enterprises in the Czech Republic, verified the awareness of companies of the options for use of cloud services. The survey took place from 28 Jan 2019 to 13 Mar 2019 and a total of 523 complete valid responses were obtained from the corporate customer segment (hereinafter the SME segment). As part of the question of determining awareness of the term "cloud" in relation to storing company data into this environment, a total of 474 respondents $(90.6 \%)$ stated that they had heard of the option to store their data in the cloud. This very significant share of positive responses is unambiguous proof that respondents from the B2B segment questioned are informed of this option. A question determining the general directions of placement of customer data in companies was answered such that, of the 523 responses, a total of 177 respondents $(33.8 \%)$ used some cloud services and only 78 respondents (14.9\%) stated that they had considered cloud services but ultimately did not use them. Among the negative responses, 145 respondents $(27.7 \%)$ stated that they had not adopted cloud services due to high prices and 111 respondents $(21.2 \%)$ stated that they had not used cloud services because they have their own servers or other repositories. To the question regarding the preference of the corporate market in the case of confrontation of regional Czech provider versus multinational companies under the prerequisite of identical offerings of services, over half $(54.7 \%)$ of the respondents stated that they would prefer a traditional Czech company over an international one. Only 79 respondents $(15.1 \%)$ stated that they would prefer an international company to a Czech one. Almost a third $(30.2 \%)$ of respondents stated that they do not think about this question when selecting cloud services. To the question as to the purposes for which companies use cloud services, the respondents stated that the most commonly used services are data repositories and tools for sharing data; this variant was chosen by a total of 150 respondents $(28.8 \%)$. The second most widely used service is email from a cloud environment; this option was stated by 145 respondents 
$(27.8 \%)$. Other services used from the cloud environment include access to remote desktops, which is used by 74 respondents (14\%), office software, which 64 respondents used (12.3\%), and accounting software, which 62 respondents used (11.9\%) [24]. As part of support for small and medium enterprises on global markets, the following model of a communication plan may be recommended for higher and more effective use of cloud repositories and services and to thereby streamline their global communications. The model is based on the basic structure of a marketing communications plan and on survey results. A basic motto for the model of marketing communication is "share, store, and send securely using the cloud". The target audience in the B2B segment are SOHO/VSE customers and SME customers, in the B2C segment households and individuals (Tab. 1)

Table 1. Target group

\begin{tabular}{|c|c|c|}
\hline Target group & Characteristics & Share \\
\hline $\begin{array}{c}\text { B2B segment - } \\
\text { SOHO / VSE } \\
\text { customers }\end{array}$ & $\begin{array}{c}\text { Typical customers of this segment are the smallest entrepreneurs with a } \\
\text { total maximum of 5-10 users who want affordable simpler products, } \\
\text { flexible communication and online payment options. Purchases are often } \\
\text { made by the company owner without deep IT knowledge. }\end{array}$ & $29 \%$ \\
\hline $\begin{array}{c}\text { B2B segment - } \\
\text { SME customers }\end{array}$ & $\begin{array}{c}\text { In the SME customer segment, there are already larger companies that } \\
\text { already operate some IT environment in some way. At the same time, } \\
\text { their IT is solved with the help of internal IT specialists or supplier } \\
\text { companies. Typical customers are IT executives or members of } \\
\text { management who require a customizable offer for their companies with a } \\
\text { high degree of flexibility. }\end{array}$ & $63 \%$ \\
\hline $\begin{array}{c}\text { B2C segment - } \\
\text { households and } \\
\text { individual users }\end{array}$ & $\begin{array}{c}\text { It is rather a marginal segment of end users, it is a traditional Czech } \\
\text { customer that is focused on Czech products, requires communication in } \\
\text { and 25-34 living in the Czech Republic, the potential use of geographic } \\
\text { regional campaigns and their further advanced segmentation. }\end{array}$ & $8 \%$ \\
\hline
\end{tabular}
$2)$.

Specifying budget is based on typical prices of individual communications tools (Table

Table 2. Marketing budget per year

\begin{tabular}{|c|c|c|c|}
\hline Title & $\begin{array}{c}\text { Number of } \\
\text { repetitions }\end{array}$ & $\begin{array}{c}\text { Project price for one } \\
\text { repetition v CZK }\end{array}$ & $\begin{array}{c}\text { Project price total } \\
\text { v CZK }\end{array}$ \\
\hline Content Marketing & & & 155000 \\
\hline Sponsored Content & 4 & 14000 & 56000 \\
\hline Landing Page & 6 & 4500 & 27000 \\
\hline White Papers / eBooks & 24 & 3000 & 72000 \\
\hline Social Media & & 5000 & $\mathbf{3 9 0 0 0 0}$ \\
\hline WhatsApp Business & 6 & 24000 & 30000 \\
\hline Facebook Business & 12 & 6000 & 288000 \\
\hline LinkedIn & 12 & & 72000 \\
\hline Online \& Web & & 3500 & $\mathbf{7 1 2 8 0 0}$ \\
\hline Blog & 24 & 4500 & 84000 \\
\hline Email Newsletter & 24 & 2500 & 308000 \\
\hline Press Releases & 12 & 6000 & 72000 č \\
\hline Online web & 12 & 24600 & 49200 \\
\hline Web Development & 2 & 21000 & 252000 \\
\hline Pay-Per-Click Marketing & 12 & 5800 & 69600 \\
\hline SEO optimization & 12 & 8000 & 48000 \\
\hline Display marketing (Banner) & 6 & & $\mathbf{2 1 8 0 0 0}$ \\
\hline Market Research & & 85000 & 170000 \\
\hline $\begin{array}{c}\text { Marketing research } \\
\text { (CAWI,CATI) }\end{array}$ & 2 & & \\
\hline
\end{tabular}




\begin{tabular}{|c|c|c|c|}
\hline $\begin{array}{c}\text { Analytical tools (PPC, Web, } \\
\text { Social) }\end{array}$ & 12 & 4000 & 48000 \\
\hline Total & & & 1475800 \\
\hline
\end{tabular}

The share of the marketing budget was defined according to specialist practice used for beginning projects (Start-ups), where the typical allocation from the sales plan is $12-20 \%$. With regard to the introductory phase of the project and the character of the environment, a higher boundary for this dispersion was selected. The timeline of execution is based on the plan of activities and the stated budget. The implementation of the individual activities was divided according to the number of repetitions in the course of a year and their duration is divided up in weeks including their assessment.

\section{Conclusion}

The global environment on the B2B market is constantly in development. One of the prerequisites for successful business is to effectively communicate between business partners using cloud repositories and services that they can better take advantage of in this environment. As the above pilot survey proved, the term "cloud" and the options of saving something "in the cloud" is familiar to over $90 \%$ of the above respondents contacted. In marketing communications the term "cloud" is commonly used [25]. Approximately 1/3 of the respondents already uses cloud services in one form or another. The penetration on the market of corporate customers is approximately $30 \%$ and represents a certain familiarity of cloud issues. In the inverse logic, therefore, the market potential for sale of cloud services has reached almost $70 \%$ of the market in the B2B customer segment. For $27 \%$ of the respondents, cloud solutions are too expensive, and they use a different variant of the solution. Nonetheless, as part of global marketing communications, these are potential customers who have already considered some cloud solution but have not adopted it due to price. It can therefore be stated with a certain likelihood that if the customer's needs were met, in this case price in particular, they would once again consider cloud services. Over half the respondents $(54.7 \%)$ prefer Czech traditional company over multinational corporations even when their products are the same. The data obtained also corresponds to the conclusions of ČSÚ and, for example, in the question of purpose of adoption of cloud services ČSÚ likewise states that the most often use case in the area of cloud computing are email services, data storage in the cloud, and operation of office services and applications [26]. From the perspective of management it is necessary for companies to align ideology and strategy with their decisions and to make better use of cloud services in the communications framework of their business. Marketing communications activities will be every more digitized and will serve more and more businesses on B2B markets. And the use of cloud solutions as a product on offer completely changes and advances the traditional marketing mix and behaviour of companies.

The result was created in solving the student project " Model of intercultural tolerance at selected universities" using objective oriented support for specific university research of the University of Finance and Administration and the project VEGA/0502/17 Consumer personality and its impact on emotional behaviour and decision making".

\section{References}

1. E. Bakhtieva, B2B digital marketing strategy: A framework for assessing digital touchpoints and increasing customer loyalty based on Austrian heating, ventilation and air conditioning industry companies, Oeconomia Copernicana 8, 463-478 (2017) 
2. B. Zurbano-Berenguer, L. Cano-Orón, I. Liberia Vayá, Gender studies in communication research: A longitudinal analysis of scientific papers published in Spanish journals indexed in the Journal Citation Reports (JCR) and the SCImago Journal Rank (SJR) (1988-2017), Journal of Research in Gender Studies 8, 169-200 (2018)

3. A. Świadek, P. Dzikowski, M. Tomaszewski, J. Gorączkowska, Sectoral patterns of innovation cooperation in Polish industry, Equilibrium. Quarterly Journal of Economics and Economic Policy 14, 183-200 (2019).

4. C. Tuffnell, P. Kral, P. Durana, T. Krulicky, Industry 4.0-based manufacturing systems: Smart production, sustainable supply chain networks, and real-time process monitoring, Journal of Self-Governance and Management Economics 7, 7-12 (2019)

5. S. Carter, A. Chu-May Yeo, Internet-enabled collective intelligence as a precursor and predictor of consumer behaviour, Economics, Management, and Financial Markets 13, 11-38 (2018)

6. G. Pricril, Does your organization really know what it's taking to market? (2014). Available at: http://spmintersections.blogspot.com/2014/12/do-you-really-know-whatyoure-taking-to.html

7. K. Trueman, Products and solutions: do you know the difference? (2016). Available at: https://hackernoon.com/products-and-solutions-do-you-know-the-difference4ff9169cefe3

8. AWS - Amazon Web Services (2018). Availavle at: https://aws.amazon.com/ industries/?nc2=h_m2\#

9. P. Korbel, Průmyslová revoluce 4.0: Za 10 let se továrny budou řídit samy a produktivita vzroste o třetinu. Hospodářské noviny, 2015-05-17 (2015)

10. P. Marcoň, Industry 4.0. Institut experimentálních technologií, VUT Brno (2016). Available at: http://www.utee.feec.vutbr.cz/iet/wpcontent/uploads/sites/2/2016/10/Industry4_0_Marcon.pdf

11. B. Dachs et al., Bringing it all back home? Back shoring of manufacturing activities and the adoption of Industry 4.0 technologies. Journal of World Business, 54, 6, Art.Nb.:101017 (2019)

12. Z. N. Zhang et al., Cloud manufacturing paradigm with ubiquitous robotic system for product customization, Robotics and Computer-Integrated Manufacturing, 60, 12-22 (2019)

13. M. Kerin, D. T. Pham, A review of emerging industry 4.0 technologies in remanufacturing, Journal of Cleaner Production, 237, Art.Nb. UNSP 117805 (2019)

14. Liu, Hu-Chen et al., Failure mode and effect analysis with extended grey relational analysis method in cloud setting, Total Quality Management\&Business Excellence, 30, 7-8, 745-767 (2019)

15. J. Parobek, H. Palus, M. Kalamarova, E. Loucanova, M. Supin, A. Krizanova, K. R. Stofkova, Energy Utilization of Renewable Resources in the European Union - Cluster Analysis Approach. Bioresources 11, 1, 984-995 (2016)

16. B. Gajdzik, W. Sroka, Analytic Study of the Capital Restructuring Processes in Metallurgical Enterprises around the World and in Poland. Metalurgija 51, 2, 265-268 (2012)

17. M. Poliak, A. Krizanova, S. Semanova, L. Stefanikova, The influence of contract form choice of the transport services ensuring on performance contracting entity requirement. Transport problems 9, 4, 153-161 (2014) 
18. A. Krizanova, L. Stefanikova, G. Masarova, Key success factors of company's intelligence program. In 8th International Scientific Conference on Business and Management (Vilnius, Lithuania, 85-92, 2014)

19. E. Kicova, M. Nadanyiova, Marketing strategies in bus transport companies and its impact on increasing the competitiveness. In 15th International Scientific Conference on Globalization and its Socio-Economic Consequences (Rajecké Teplice, Slovakia, 292-296, 2015)

20. Data Center Certification, Standards and Compliance - Management Mania.com. Available at: https://managementmania.com/en/data-center-certification-standardsand-compliance

21. What Is a VPN? - Virtual Private Network - Cisco. Available at: https://www.cisco.com/c/en/us/products/security/vpn-endpoint-security-clients/whatis-vpn.html

22. Capital Expenses vs. Operating Expenses (2018). Available at: https://www.investopedia.com/terms/o/operating_expense.asp

23. GTAI - Germany trade \& invest. Industrie 4.0 Germany Report and Outlook (2018) Available at: https://www.gtai.de/GTAI/Content/EN/Invest/_SharedDocs/Downloads/ GTAI/Industry-overviews/industrie4.0-germany-market-outlook-progress-reporten.pdf?v=12

24. V. Šimíček, Asistované zhodnocení a príprava marketingového plánu pro společnost Algotech a.s. se zaměrením na online marketing a prostředí prümyslu 4.0. Thesis 2019, University of Finance and Administration Prague (2019)

25. P. Kotler et al., Marketing 4.0: moving from traditional to digital. (Hoboken, New Jersey: Wiley, 2017)

26. V. Mař́k et al., Národní iniciativa Průmysl 4.0. Praha: Ministerstvo Průmyslu a Obchodu (2015). Available at: https://www.businessinfo.cz/app/content/ files/dokumenty/narodni-iniciativa-prumysl-40.pdf 